\title{
Hip Flexion Weakness following Transpsoas Interbody Fusion
}

\section{Fraqueza de flexão do quadril após fusão lombar por via transpsoas}

\author{
Joes Nogueira-Neto ${ }^{1}$ Luis Marchi ${ }^{1}$ Rafael Aquaroli ${ }^{2}$ Elder Camacho ${ }^{2}$ Rodrigo Amaral ${ }^{1}$ \\ Leonardo Oliveira $^{1}$ Etevaldo Coutinho ${ }^{1}$ Luiz Pimenta ${ }^{1}$
}

${ }^{1}$ Instituto de Patologia da Coluna, São Paulo, SP, Brazil

Address for correspondence Joes Nogueira-Neto, PhD, Instituto de

${ }^{2}$ Instituto Thera, São Paulo, SP, Brazil

Patologia da Coluna (IPC), Rua Vergueiro, 1421, Conjunto 305, São Paulo,

Arq Bras Neurocir 2019;38:102-105. SP 04104-000, Brazil (e-mail: g.pokorny@patologiadacoluna.com.br).

\begin{abstract}
Keywords

- extreme lateral interbody fusion

- hip flexion

- spine

- weakness

- psoas
\end{abstract}

\section{Resumo}

Objective The present work evaluated the motor deficit resulting from the psoas muscle access through the extreme lateral interbody fusion (XLIF) approach.

Methods This was a prospective, non-randomized, controlled, single-center study with 60 patients, with a mean age of 61.8 years old. All of the subjects underwent a lateral transpsoas retroperitoneal approach for lumbar interbody fusion with electroneuromyographic guidance and accessing 1 to 3 lumbar levels (mean level, 1.4; 63\% cases in only 1 level; $68 \%$ cases included L4-L5). The isometric hip flexion strength in the sitting position was determined bilaterally with a handheld dynamometer (Lafayette Instrument, Lafayette, IN, USA). The mean value of three peak force measurements (N) was calculated. Standardized isometric strength tests were performed before the procedure and at 10 days, 6 weeks, 3 months and 6 months postsurgery.

Results Ipsilateral hip flexion was diminished $(p<0.001)$ at the early postoperative period, but reached preoperative values at 6 weeks $(p>0.12)$. The mean hip flexion measures before the procedure and at 10 days, 6 weeks, 3 months and 6 months after surgery were the following, respectively: $13 \mathrm{~N} ; 9.7 \mathrm{~N} ; 13.7 \mathrm{~N} ; 14.4 \mathrm{~N}$; and $16 \mathrm{~N}$ (ipsilateral); $13.3 \mathrm{~N} ; 13.4 \mathrm{~N} ; 15.3 \mathrm{~N} ; 15.9 \mathrm{~N}$; and $16.1 \mathrm{~N}$ (contralateral). Neither the level nor the number of treated levels had a clear association with thigh symptoms, but hip flexion weakness was the most common symptom.

Conclusions Patients in the early postoperative period of transpsoas access presented hip flexion weakness. However, this weakness was transient, and electroneuromyography use is still imperative in transpsoas access. In addition, patients must be thoroughly educated about hip flexion weakness to prevent falls in the immediate postoperative period.

Objetivo Avaliar o déficit motor decorrente do acesso através do músculo psoas na técnica de fusão intersomática por via extremo-lateral (XLIF, na sigla em inglês).

Métodos Estudo prospectivo, não randomizado, controlado, único centro. Total de 60 pacientes com média de 61,8 anos. Todos os participantes passaram por fusão intersomática lombar por acesso lateral retroperitoneal com monitoração eletroneuromiográfica. Foram operados de 1 a 3 níveis nesses casos (média de 1,4; 63\% received

May 3, 2017

accepted

August 1, 2017
DOI https://doi.org/

10.1055/s-0037-1606283. ISSN 0103-5355.
Copyright $\odot 2019$ by Thieme Revinter Publicações Ltda, Rio de Janeiro, Brazil
License terms

c) $(1) \$$ 
eram de apenas um nível; $68 \%$ incluíram L4-L5). A força de flexão isométrica do quadril em posição sentada foi determinada bilateralmente com um dinamômetro de mão (Lafayette Instrument, Lafayette, IN, USA). As médias das medidas de 3 picos de força $(\mathrm{N})$ foram calculadas. Testes isométricos padronizados foram realizados antes e em 10 dias, 6 semanas, 3 e 6 meses após a cirurgia.

Resultados A força de flexão do quadril no lado ipsilateral diminuiu $(p<0,001)$ no pós-operatório imediato, mas em 6 semanas atingiu os valores pré-operatórios. As médias de pré-operatório e 10 dias, 6 semanas, 3 meses e 6 meses após a cirurgia para flexão de quadril medidas foram, respectivamente: (ipsilateral) $13 \mathrm{~N} ; 9,7 \mathrm{~N} ; 13,7 \mathrm{~N}$;

\section{Palavras-chave}

- fusão intersomática por via extremolateral

- flexão de quadril

- coluna

- fraqueza

- psoas
$14,4 \mathrm{~N} ; 16 \mathrm{~N}$; (contralateral) 13,3 N; 13,4 N; 15,3 N; 15,9 N; 16,1 N. Nem o nível nem o número de níveis tratados tiveram clara associação com sintomas na coxa, mas a fraqueza de flexão de quadril foi o sintoma mais encontrado.

Conclusões $\mathrm{O}$ pós-operatório imediato do acesso transpsoas apresentou fraqueza de flexão de quadril após a cirurgia. Entretanto, essa ocorrência é transiente, e o uso da eletroneuromiografia é essencial no acesso transpsoas. Somado a isso, a educação do paciente deve ser amplamente aplicada para alertar sobre a possibilidade de fraqueza de flexão de quadril com o intuito de prevenir quedas no período pós-operatório imediato.

\section{Introduction}

Degenerative diseases of the lumbar spine can cause back pain irradiating to the legs that may compromise the health and the well-being of the patient. These diseases range from intervertebral disc degeneration to vertebral canal stenosis. ${ }^{1}$ Treatments vary on a case-by-case basis, from conservative therapy in milder conditions to interbody fusion in patients with more severe radiological and clinical features. ${ }^{2}$

Interbody fusion is a surgical treatment for various degenerative diseases of the lumbar spine. Vertebral bodies can be fused through some surgical techniques, including interbody fusion by extreme lateral access via transpsoas or extreme lateral lumbar interbody fusion (XLIF), ${ }^{3}$ which has been widely used and is highly applicable for several pathologies. ${ }^{3,4}$ However, like any other surgical approach, this access has disadvantages, such as the risk of injury to the lumbar plexus, which can lead to postoperative motor and sensory deficits in the lower limbs. ${ }^{3}$ Considering the inherent risks of this surgical technique, the present study aimed to evaluate the flexion strength of the hip before and after surgical intervention in cases of lumbar spine degeneration.

\section{Materials and Methods}

This was a prospective, single-center, non-randomized study. The present study was approved by the Research Ethics Committee of the Hospital Nove de Julho, São Paulo, SP (66616317.0.0000.5455). A total of 60 patients (39 females), with a mean age of 61.8 years old, were submitted to the XLIF technique by the same spinal team. The inclusion criteria were: patients with degenerative lumbar spine submitted to interbody fusion by the XLIF surgical technique after conservative treatment failure for at least 6 months. One to 3 lumbar levels were instrumented (mean level, 1.37; $63 \%$ cases in only 1 level; $68 \%$ cases involving L4-L5). Surger- ies were performed with retroperitoneal lateral access via the transpsoas approach by senior spinal surgeons. ${ }^{4}$

The hip flexion strength was evaluated in the sitting position with a handheld dynamometer (Lafayette Instrument, Lafayette, IN, USA). ${ }^{5}$ Three measurements of peak force $(\mathrm{N})$ were performed, and the means were calculated. These measurements were assessed in pre- and postoperative evaluations at 10 days, 6 weeks, 3 and 6 months postsurgery, both ipsilateral and contralateral to the surgical access. The strength in both sides was compared. Pain on both sides was also assessed using the visual analogue scale (VAS) questionnaire. ${ }^{6}$ Descriptive and comparative statistical analyses were performed with the SPSS software (IBM SPSS, Armonk, NY, USA). The comparative statistical analyses between groups were performed using the student $t$-test and an $\alpha$ value of 0.05 .

\section{Results}

Lateral interbody fusions were performed in 60 patients. The mean age was 61.8 years old (ranging from 22 to 85 years old), and 39 patients were female. Among the 60 cases included in the present study, 38 were single-level arthrodesis, and 41 involved the L4-L5 level (-Table $\mathbf{1}$ ).

A significant $25.4 \%$ reduction in the strength of the psoas at the instrumented side was observed between the preoperative measures and those obtained at the $10^{\text {th }}$ day visit (13 N and $9.7 \mathrm{~N}$, respectively) (-Fig. 1). Despite this decrease at the $1^{\text {st }}$ postoperative follow-up, the force level returned to baseline 6 weeks after the surgery, and it was sustained until the $3^{\text {rd }}$ month. At the end of the study, the hip flexion strength was higher than before the surgery $(16 \mathrm{~N})$.

The reduction of the ipsilateral psoas strength at the $1^{\text {st }}$ postoperative follow-up was not observed on the contralateral side (13.3 N and $13.4 \mathrm{~N}$, respectively). The strength remained constant until the $10^{\text {th }}$ day visit, followed by a 
Table 1 Demographics and surgical data

\begin{tabular}{|l|l|}
\hline Cases & 60 \\
\hline Male/female ratio (\%) & $35 / 65$ \\
\hline Mean age & $61.8(22-85)$ \\
\hline Surgical time (minutes) & $114.3(30-400)$ \\
\hline Blood loss (mL) & $166(50-1,700)$ \\
\hline Operated levels (mean) & 1.37 \\
\hline 1 level & $42(70 \%)$ \\
\hline 2 levels & $15(25 \%)$ \\
\hline 3 levels & $3(5 \%)$ \\
\hline Postoperative walking (hours) & $20(0.5-120)$ \\
\hline
\end{tabular}

$20 \%$ increase in subsequent visits, reaching $16.1 \mathrm{~N} 6$ months postsurgery.

No differences were observed between the strength of the ipsilateral and of the contralateral sides before the surgery $(p=0.71)$. However, a $38 \%$ increase in the hip flexion strength was observed on the contralateral side $(13.4 \mathrm{~N})$ compared with the ipsilateral side $(9.7 \mathrm{~N}) 10$ days postsurgery, a difference that ceased to exist after the 6 -week evaluation until the end of the study, at the 6-month visit ( $p>0.05$ ).

Regarding the pain in the ipsilateral and contralateral sides, it was observed that, even before the surgery, there was already $27.4 \%$ more pain on the instrumented side $(6.05$ and 4.75 , respectively). This difference remained until the 3month evaluation, leaving no distinction between both sides at the 6-month visit (2.77 and 2.57, respectively).

Some adverse effects were observed during the present study. In addition to the reduction in the strength of the psoas, five patients also presented with quadriceps deficit. However, all of the patients regained both psoas and quadriceps strength, with no permanent deficit. No case has progressed to reoperation due to plexopathy. In addition to lumbar XLIF, 1 patient underwent a lateral arthrodesis at the thoracic level, and, in this procedure, the intraoperative bleeding was more pronounced $(1,700 \mathrm{~mL})$. However, this blood loss did not cause additional harm to the patient.

\section{Discussion}

Interbody fusion is a widely used surgical approach for the treatment of lumbar spine degenerative diseases. ${ }^{3}$ To achieve this goal, extreme transpsoas lateral access has great applicability and biomechanical advantages over other options, mainly for maintaining the integrity of the posterior and anterior longitudinal ligaments, the latter the most important stabilizing ligament of the spine. ${ }^{7,8}$ To reach the disc space, XLIF uses the transpsoas approach, crossing between the muscular fibers. This is one of the main spinal stabilizing muscles, and it is transected by a nerve network called the lumbar plexus. To minimize the risks of nerve damage, this technique uses a directional monitoring system that evaluates the conduction of nerve impulses to the extremities, preserving neural integrity. However, even with the navigation tool, this technique still has postoperative side effects. Reduction of hip flexion strength is the main postoperative effect of XLIF. This strength is mainly performed by the psoas muscle, which is transected by dilators for disc space access. Literature studies commonly assess the frequency of this weakness in XLIF patients. ${ }^{8-12}$ This phenomenon is usually reported by the patient, and it can often go unnoticed or be overlooked. In addition, only a few papers report strength degree reductions. In a different way, the present work evaluates this parameter in a force scale in $\mathrm{N}$, using measurements obtained with a dynamometer in an objective and systematic form.

In the present study, clinical parameters were evaluated in five different visits. Results showed a significant decrease of $\sim 24 \%$ in the hip flexion strength on the ipsilateral side shortly after the surgery, returning to preoperative values 6 weeks after the procedure. Although not assessing psoas strength in the same way as the present study, Sharma et al observed a similar phenomenon of postsurgical hip flexion strength reduction, with all of the patients returning to preoperative strength values at 6 weeks. ${ }^{8}$ Similarly, other studies in the literature have also shown that hip flexion weakness is a transient phenomenon. ${ }^{9,11}$ This effect is transient since it is not a plexopathy, but a relaxation of the intrinsic innervation of the psoas itself, causing weakness, which is transitory, provided that the muscle is stimulated with regular daily activity. ${ }^{13}$ In

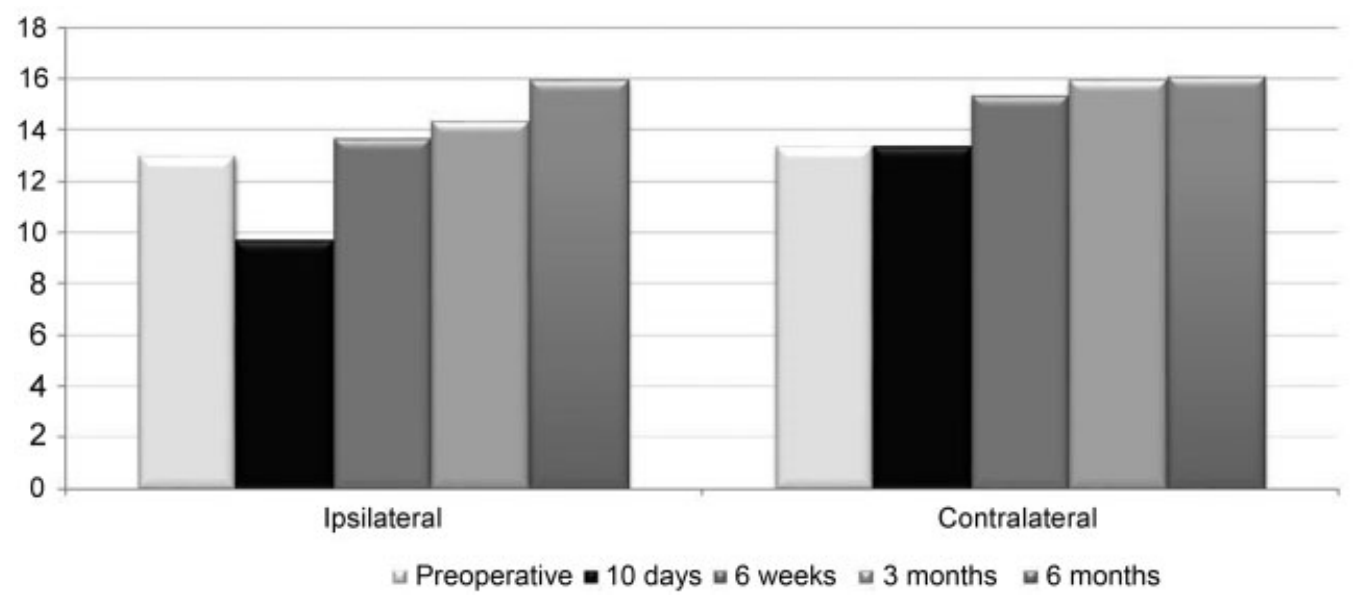

Fig. 1 Ipsilateral and contralateral mean hip flexion forces before and after extreme lateral interbody fusion (XLIF). 
addition to this side effect, it was observed that $8.3 \%$ of the patients presented with quadriceps weakness after the surgery as an adverse effect, a number similar to those observed in other studies in the literature. ${ }^{8,9,11,12}$

The present study has some limitations. First, since it was conducted at a single research center, the small number of patients diminishes the power and the strength of the study. Second, the lack of data about psoas muscle retraction time from all of the patients is also a limitation, since it is not possible to directly relate this parameter with the presence of postoperative symptoms.

\section{Conclusion}

In summary, the present study brings a quantitative measure in a direct force scale. Thus, it does not depend on the report of the patients regarding the possible side effect of decreased hip flexion strength. This is a common side effect on the ipsilateral side due to the retraction of the psoas muscle, which is, however, transient. The patient should be instructed before surgery about the possibility of this phenomenon, to avoid possible falls-resulting from this loss of strength in the first days postsurgery-that could compromise a better postoperative result. Studies with greater casuistry are necessary to better understand these side effects and the complications resulting from lateral access.

Conflicts of Interest

The authors have no conflicts of interest to declare.

\section{References}

1 Clarençon F, Law-Ye B, Bienvenot P, Cormier É, Chiras J. The Degenerative Spine. Magn Reson Imaging Clin N Am 2016;24 (03):495-513
2 Glassman SD, Carreon LY, Djurasovic M, et al. Lumbar fusion outcomes stratified by specific diagnostic indication. Spine J 2009;9 (01):13-21

3 Mobbs RJ, Phan K, Malham G, Seex K, Rao PJ. Lumbar interbody fusion: techniques, indications and comparison of interbody fusion options including PLIF, TLIF, MI-TLIF, OLIF/ATP, LLIF and ALIF. J Spine Surg 2015;1(01):2-18

4 Ozgur BM, Aryan HE, Pimenta L, Taylor WR. Extreme Lateral Interbody Fusion (XLIF): a novel surgical technique for anterior lumbar interbody fusion. Spine J 2006;6(04):435-443

5 Thorborg K, Petersen J, Magnusson SP, Hölmich P. Clinical assessment of hip strength using a hand-held dynamometer is reliable. Scand J Med Sci Sports 2010;20(03):493-501

6 Downie WW, Leatham PA, Rhind VM, Wright V, Branco JA, Anderson JA. Studies with pain rating scales. Ann Rheum Dis 1978;37(04):378-381

7 Talia AJ, Wong ML, Lau HC, Kaye AH. Comparison of the different surgical approaches for lumbar interbody fusion. J Clin Neurosci 2015;22(02):243-251

8 Sharma AK, Kepler CK, Girardi FP, Cammisa FP, Huang RC, Sama AA. Lateral lumbar interbody fusion: clinical and radiographic outcomes at 1 year: a preliminary report. J Spinal Disord Tech 2011;24(04):242-250

9 Phillips FM, Isaacs RE, Rodgers WB, et al. Adult degenerative scoliosis treated with XLIF: clinical and radiographical results of a prospective multicenter study with 24-month follow-up. Spine 2013;38(21):1853-1861

10 Khajavi K, Shen A, Lagina M, Hutchison A. Comparison of clinical outcomes following minimally invasive lateral interbody fusion stratified by preoperative diagnosis. Eur Spine J 2015;24(03, Suppl 3):322-330

11 Tohmeh AG, Rodgers WB, Peterson MD. Dynamically evoked, discrete-threshold electromyography in the extreme lateral interbody fusion approach. J Neurosurg Spine 2011;14(01):31-37

12 Anand N, Rosemann R, Khalsa B, Baron EM. Mid-term to longterm clinical and functional outcomes of minimally invasive correction and fusion for adults with scoliosis. Neurosurg Focus 2010;28(03):E6

13 Cummock MD, Vanni S, Levi AD, Yu Y, Wang MY. An analysis of postoperative thigh symptoms after minimally invasive transpsoas lumbar interbody fusion. J Neurosurg Spine 2011;15(01):11-18 